\title{
DAMPAK REKLAMASI PANTAI TERHADAP KONDISI SOSIAL EKONOMI MASYARAKAT PESISIR LAINO
}

\author{
Alfa Srianti ${ }^{1}$ \\ ${ }^{1}$ Alumni Pendidikan Geografi FKIP UHO
}

\begin{abstract}
Abstrak:Penelitian ini bertujuan untuk mengetahui apa saja dampak sosial ekonomi masyarakat pesisir laino yang timbul setelah adanya reklamasi pantai dan u ntuk mengetahui seberapa besar pengaruh yang ditimbulkan dengan adanya reklamasi pantai terhadap aktivitas ekonomi masyarakat pesisir laino yang ada di Kelurahan Laiworu Kecamatan Batalaiworu. Metode penelitian yang digunakan dalam penelitian ini adalah kualitatif dengan menggunakan teknik pengumpulan data berupa observasi, wawancara dan dokumentasi Setelah seluruh informasi atau data dikumpulkan, baik melalui proses observasi (pengamatan), wawancara maupun dokumentasi. maka selanjutnya peneliti melakukan analisis data dengan mengunakan deskriptif kualitatif.Hasil penelitian menunjukan terdapat dampak yang ditimbulkan dengan adanya reklamasi yaitu dampak secara sosial ekonomi karna adanya reklamasi pantai yaitu pada bidang pendidikan,kesehatan,perumahan dan pendapatan dimana reklamasi memberikan dampak yang signifikan atau lebih menguntungkan bagi masyarakat yang tinggal diarea penimbunan laut dimana sebagian masyarakat tidak mempermasalahkan adanya penimbunan karena pada kenyataanya masyarakat yang tinggal di pesisir laino tidak semua menggantungkan hidup pada laut hanya sebagian kecil yang mencari penghidupan dilaut dan lebih banyak pekerjaan di darat dan tidak mempermasalahkan dengan adanya reklamasi jadi reklamasi pantai di pesisir laino lebih berdampak baik terhadap kehidupan sosial ekonomi masyarakat yang tinggal diarea pesisir laino.
\end{abstract}

Kata Kunci: Dampak, Ekonomi , dan Proses Reklamasi Pantai. 


\title{
IMPACT OF BEHAVIOR RECLAMATION ON SOCIAL ECONOMIC CONDITIONS OTHER COASTAL COMMUNITIES
}

\author{
Alfa srianti ${ }^{1}$ \\ ${ }^{1}$ Alumnus Geography Education Geography FKIP UHO
}

\begin{abstract}
This study aims to determine what are the socio-economic impacts of other coastal communities arising after coastal reclamation and to find out how much influence caused by coastal reclamation to economic activity of other coastal communities in Laiworu Subdistrict, Batalaiworu Subdistrict. Research method used in this research is qualitative by using data collecting technique such as observation, interview and documentation After all information or data collected, either through process observation (observation), interview and documentation. then the researchers conducted data analysis using qualitative descriptive. The results of research showed that there was an impact caused by the reclamation of the socio-economic impact because of the beach reclamation that is in the field of education, health, housing and income where the reclamation has a significant or more beneficial impact people living in the landfill area where some people do not question the existence of hoarding because in fact the people living in other coastal areas not all rely on the sea only a small part who seek livelihood at sea and more work on land and do not question with the reclamation so beach reclamation in other coastal areas have a better impact on the socio-economic life of people living in other coastal areas.
\end{abstract}

\section{Keywords: Impact, Economy, and Beach Reclamation Process.}

\section{PENDAHULUAN}

Wilayah pesisir dan lautan Indonesia yang kaya dan beragam sumber daya alamnya telah dimanfaatkan oleh bangsa Indonesia sebagai salah satu sumber bahan makanan utama, khususnya protein hewani, sejak berabad-abad lamanya. Sementara itu, kekayaan hidrokarbon dan mineral lainnya yang terdapat di wilayah ini juga telah dimanfaatkan untuk menunjang pembangunan ekonomi nasional sejak Pelita I. Selain menyediakan berbagai sumber daya tersebut, wilayah pesisir dan lautan Indonesia memiliki berbagai fungsi lain, seperti transportasi dan pelabuhan, kawasan industri, agribisnis dan agroindustri, rekreasi dan pariwisata, serta kawasan pemukiman dan tempat pembuangan limbah.

Wilayah pesisir sangat menarik perhatian manusia baik pada masa dahulu maupun sekarang. Seiring dengan perkembangan peradaban dan kegiatan sosial ekonominya. Manusia memanfaatkan wilayah pesisir untuk berbagai kepentingan seperti sebagai tempat mencari nafkah, permukiman, perkotaan, kawasan industry, bandara, pelabuhan maupun sebagai tempat berekreasi. Konsekuensi yang muncul dari pesatnya pembangunan di wilayah 
pesisir antara lain adalah masalah penyediaan lahan bagi aktivitas sosial ekonomi dan gangguan terhadap lingkungan. Hal ini mengakibatkan terhambatnya perekonomian di wilayah pesisir Laino dikarenakan lahan yang terbatas.

Dilihat dari Berbagai Dampak dari reklamasi pantai disekitar pesisir laino bisa menguntungkan dan bahkan bisa merugikan masyarakat pesisir oleh karena terkait dengan masalah tersebut,maka penulis tertarik untuk melakukan penelitian terhadap

"dampak reklamasi pantai terhadap sosial ekonomi masyarakat pesisir Laino."

Reklamasi Pantai, yaitu kegiatan menimbun atau memasukkan material tertentu di kawasan Pantai dengan maksud untuk memperoleh lahan kering (Nurmandi, 1999). Berdasarkan UU No. 27 Tahun 2007 reklamasi adalah kegiatan yang dilakukan oleh orang dalam rangka meningkatkan manfaat sumber daya lahan ditinjau dari sudut lingkungan dan sosial ekonomi dengan cara pengurugan, pengeringan lahan atau drainase. Berdasarkan Permen PU No. 40 Tahun 2007 Kawasan reklamasi pantai adalah kawasan hasil perluasan daerah pesisir pantai melalui rekayasa teknis untuk pengembangan kawasan baru.

Menurut Kamus Besar Bahasa Indonesia (KBBI) dampak merupakan benturan, pengaruh kuat yang mendatangkan akibat (baik negatif maupun positif). Dampak juga dapat diartikan sebagai benturan yang cukup hebat antara dua benda sehingga menyebabkan perubahan yang berarti dalam momentum sistem yang mengalami benturan itu. Dilihat dari sisi ekonomi, dampak berarti bahwa pengaruh suatu penyelenggaraan kegiatan terhadap perekonomian (KBBI Online, 2014).

Soemarwoto,

menyatakan bahwa dampak, adalah suatu perubahan yang terjadi akibat dari suatu aktifitas bisa menguntungkan atau tidak menguntungkan, tergantung ada tujuan dari suatu aktivitas.dampak lingkungan misalnya lebih berkonotasi pada aktivitas yang tidk menguntungkan/merugikan sebagai akibat dari suatu perlakuan terhadap sumber alam.selanjutnya “ dampak pendidikan" lebih bermakna positif atau menguntungkan sebab dengan adanya perlakuan pendidikan terhadap masyarakat akan mendorong peningkatan kualitas masyarakat itu sendiri.

Dampak (impacts) adalah ukuran tingkat pengaruh sosial, ekonomi, lingkungan, atau kepentingan umum lainnya yang dimulai oleh capaian kenerja setiap indikator dalam suatu kegiatan (Dicktus, 2013).

Dampak sosial ekonomi dapat dilihat dari sisi positif dan negative sehingga dapat lebih berimbang dalam memberikan penilaian. Beberapa hal yang bersifat positif yaitu meningkatnya kelayakan dan kenyamanan usaha,terbukanya kesempatan kerja, perubahan status menjadi pedagang legal.Dampak negatif yaitu menurunnya pendapatan, meningkatnya biaya operasional,melemahnya jaringan sosial, dan menurunnya kesempatan pedagang untuk ikut dalam kelompok-kelompok sosial non formal(Sinaga, 2004:134).

Teori Weber mengemukakan bahwa tindakan ekonomi dapat dipandang sebagai tindakan sosial 
selama tindakan tersebut memperhatikan tingkah laku orang lain. Sebab secara umum, di kalangan pedagang pasar tradisional terdapat interaksi sosial, hubungan sosial dan jaringan yang dibangun untuk menopang usaha mereka (Heriyanto, 2012).

Menurut soekanto (1990:22-23)

bahwa kehidupan sosial masyarakat yakni kehidupan kelompok manusia secara bersama-sama yang bercampur dalam waktu yang cukup lama,dalam satu kesatuan dan merupakan suatu hidup bersama. Kehidupan sosial adalah syarat minimal yang harus dipenuhi demi eksisnya suatu kehidupan sosial. Unsur-unsur dasar tersebut merupakan kondisi-kondisi yang harus dipelihara dan dikembangkan agar kehidupan sosial dapat bertahan.Kehidupan sosial sama halnya dengan kehidupan bersama masyarkat tentunya mempunyai anggota lebih dari dua orang yang saling berhubungan dan merupakan proses social (kehidupan sosial) adalah aktivitas yang berkenaan dengan prosesproses sosial.

\section{METODE PENELITIAN}

Penelitian ini telah dilaksanakan pada bulan Juli 2017, di area Reklamasi Pantai khususnya di area Pesisir Laino yang bertempat dikelurahan Laiworu Kecamatan Batalaiwoaru Kabupaten Muna. Pemilihan tempat lokasi penelitian ini sengaja karna pertimbangan bahwa area reklamasi yang ada di kelurahan laiworu ada pemukiman masyarakat pesisir.
Untuk memperoleh data dan informasi yang valid, akurat serta menyakinkan mengenai dampak reklamasi pantai terhadap sosial ekonomi masyarakat pesisir laino maka sumber data sangat dibutuhkan. Sumber data dari penelitian ini adalah masyarakat pesisir yang tinggal di dekat area reklamasi pantai.

Teknik atau cara pengumpulan data yang akan dilakukan meliputi:

1. Observasi, dilakukan dengan cara mengamati secara langsung obyek yang diteliti yang kemudian dilakukan penarikan kesimpulan.

2. Wawancara, dilakukan secara mendalam yaitu dengan mengajukan pertanyaan kepada informan terutama yang relevan dengan fokus penelitian. hal ini dilakakuakn berdasarkan pedoman wawancara yang telah disiapkan .

3. Dokumentasi, dilakukan dengan cara pengumpulan dan membaca literature serta laporan ilmiah yang dapat menunjang penelitian ini.

Analisis data dilakukan secara deskriptif kualitatif yaitu meneliti dan menelaah data dan segala informasi. Data yang diperoleh kemudian diuraiakan dalam bentuk uraian secara logis dan sistematis yang didukung dengan argumentasi ilmiah untuk menjawab permasalahan yang ada pada penelitian ini. 


\section{HASIL PENELITIAN}

\section{Dampak Reklamasi Terhadap Kondisi Sosial Ekonomi Masyarakat Pesisir Laino a. Bidang Kesehatan}

Kesehatan adalah salah satu unsur penting dalam hidup, karena dengan kondisi kesehatan yang baik maka aktivitas untuk menjalankan kativitas sehari-hari dalam mencari nafkah akan berjalan dengan lancar.
Kesehatan suatu hal yang sangat penting bagi setiap orang dimana apabila kesehatan terganggu akan berpengaruh terhadap aktivitas yang dilakukan. Bagi orang yang berstatus sosial tinggi tidak akan khawatir dengan biaya pengobatan yang mahal tetapi berbeda halnya dengan orang yang berstatus biasa/rendah.

1. Frekuensi anggota keluarga yang sakit selama 6 bulan

Tabel 3.1 Anggota keluaraga yang sakit selama 6 bulan

\begin{tabular}{clcc}
\hline No & Kondisi kesehatan & Jumlah & $\begin{array}{c}\text { Presentase } \\
\%\end{array}$ \\
\hline 1. & Ada & 3 & 13,63 \\
\hline 2. & Tidak ada & 19 & 86,36 \\
\hline & Jumlah & 22 & 100 \\
\hline
\end{tabular}

\section{Sumber :data primer (2017)}

Berdasarkan data diatas

menunjukan bahwa responden mempunyai kondisi kesehatan yang baik dimana sebanyak $22(86,36 \%)$ responden mengaku bahwa keluarganya selalu dalam kondisi sehat sedangkan $3(13,63 \%)$ responden mengaku bahwa sebagian keluarganya dalam kondisi yang kurang sehat dalam 6 bulan terakhir.

\section{b. . Bidang Perumahan}

Rumah merupakan salah satu bagian dari kehidupan manusia dimana merupakan kebutuhan dasar yang harus dipenuhi oleh makhluk yang berpikir,karena berfungsi bagi masyarakat tidak hanya sekedar pemenuhan kebutuhan tempat tinggl atau tempat berlindung saja akan tetapi diselaraskan dengan kebutuhan lain seperti keamanan dan kenyamanan dalam lingkungan keluarga maupun masyarakat sekitarnya.

Selain sandan dan pangan tempat tinggal merupakan salah satu bagian dari kebutuhan primer manusia.kondisi tempat tinggal atau perumahan memberikan gambaran mengenai tingkat kesejahteraan keluarga.perumah yang ideal adalah perumahan yang memenuhi persayaratan kesehatan dan lokasinya mudah untuk menjangkau beberapa fasilitas pasar,kesehatan dan pendidikan.

\section{c. Mata Pencaharian}

Mata pencaharian merupakan kegiatan masyarakat yang menjadi Rutinitas sebagai lahan mencari penghasilan guna pemenuhan kehidupan yang berkelanjutan sehingga mata pencaharian adalah salah satu pendorong 
seseorang menikmati dan menyanggupi kebutuhan kehidupannya serta mempengaruhi pola hidup mereka.

Sebelum reklamasi dilakukan masyarakat pesisir yang tinggal diarea pesisir laino memiliki profesi yang beragam dimana ada pns,pedagang dan nelayan.

Namun setelah dilakukan reklamasi lebih mempengaruhi pendapatan nelayan yang tinggal diarea reklamasi menghambat aktivitas nelayan aalagi pada saat reklamasi pantai berlangsung dimana masyarakat nelayan sangat kesulitan Dengan adanya penimbunan/reklamasi sehingga menyebabkan mata pencaharian masyarakat pesisir laino menjadi beragam, dimana beragamnya mata pencaharian khususnya nelayan yang dulu hanya mengandalkan bidang perikanan (nelayan dan pedagang ikan) sebagai mata pencaharian sekarang makin bertambah bukan hanya dari perikanan akan tetapi banyak alternative lain diluar bidang perikanan.

Mata pencaharian yang ada sebelum adanya reklamasi dibidang perikanan yaitu nelayan,dan pedagang ikan pekerjaan tersebut sudah dilakononi masyarkat setempat sejak lama. Selain itu juga Sesuai dengan yang dikatakan setelah reklamasi selesai, kesempatan masyarakat mendapatkan pekerjaan meningkat dan berkurangnya masyarakat dengan pekerjaan tidak tetap. Pada saat setelah dilakukan penimbunan masyarakat mulai beralih pekerjaan dari yang kerjanya di laut beralih menjadi buruh, tukang kayu ,dan pedagang karena kondisi pesisir yang tidak memungkinkan sebagai tempat bekerja akhirnya mereka beralih kedaratan.a.kan teetapi tidak semua beralih pekerjaan ada sebagian masyarakat masih mempertahankan pekerjaannya setellah dilakuakan reklamasi dikarenakan tidak adanya keterampilan lain selain pekerjaan tersebut.

Peluang berusaha dan kesempatan kerja merupakan dampak positif karena melibatkan masyarakat secara luas selama penerimaan tenaga kerja untuk proyek reklamasi yang bisa membuka lapangan pekerjaan baru bagi masyarakat di sekitarnya.

Hal tersebut berpengaruh terhadap penurunan jumlah rata-rata penghasilan yang diperoleh masyarakat sehingga banyak yang kemudian memutuskan untuk berganti profesi menjadi pedagang atau tukang bangunan di area pesisir laino khususnya bagi masyarakat yang menggantungkan hidupnya pada laut. Perubahan alih profesi dari nelayan menjadi pedagang ini juga memicu persaingan antara pedagang - pedagang akibat bertambah banyaknya yang memilih untuk berdagang. Selain perubahan profesi masyarakat sekitar, bertambah banyaknya masyarakat yang membuka warung, khususnya di daerah sekitar Pantai laino menimbulkan persaingan tak sehat dengan warga yang lebih dulu mendiami daerah tersebut, perilaku cenderung kasar, dan semakin beratnya tantangan hidup sehingga tingginya angka kejahatan. Dari keramaian Pasar panjang laino sebagai ruang publik juga kemudian timbul permasalahan kemacetan akibat banyaknya kendaraan yang menuju ke dalam pasar.

Reklamasi sendiri menjadikan Pantai Laino lebih tertata. Kawasan tersebut kini dimanfaatkan sebagai ruang publik berupa ruang terbuka untuk 
sarana pendidikan dan bagi masyarakat yang berjualan. Di area reklamasi tersebut didirikan pasar panjang laino sehingga banyak Aktivitas yang terjadi di ruang publik pesisir Pantai Laino tersebut terkadang berlangsung dari pagi hari hingga malam hari. Aktivitasnya yang terjadi adalah aktivitas jual beli. Pada malam hari dimanfaatkan oleh kalangan muda sebagai tempat akhir pekan mereka sambil menikmati suasana taman. Selain itu, banyak pedagang kaki lima memanfaatkan ruang terbuka Pantai Laino sebagai tempat berjualan. Beberapa kelompok pedagang bahkan berjualan sepanjang hari, terutama mereka yang skala ekonominya semakin meningkat. $\mathrm{n}$.

Kegiatan berjualan bukan hanya dilakukan di pasar melainkan di area penimbunan pun terjadi pesisir Pantai Laino tersebut. Mereka yang berjualan tidak hanya yang menjual ikan tetapi juga menjual makanan yang bisa dinikmati dengan ikan bakar . sebagian
Hasil reklamasi pesisir Pantai Laino juga didirikan sebagai pasar panjang laino dan sebagai tempat pemukiman nelayan . Masyarakat secara langsung mendapat manfaat ekonomi.

\section{d. Pendapatan}

Pendapatan merupakan hasil dari pekerjaan dan hasil dari mata pencaharian yang bernilai dengan faktor uang dalam satuan waktu.pendapatan dibagi dua yaitu pendapatan utama/pokok dan pendapatan tambahan.

1. Pendapatan pokok

Pendapatan pokok merupakan hasil bernilai uang yang didapat dari pekerjaan pokok. Tingkat pendapatan

Tabel.3.2 Pendapatan Pokok Responden

\begin{tabular}{|c|c|c|c|c|}
\hline \multirow[t]{3}{*}{ Pendapatan } & \multicolumn{4}{|c|}{ Pendapatan Utama Responden } \\
\hline & \multicolumn{2}{|r|}{$\begin{array}{l}\text { Sebelum } \\
\text { Reklamasi }\end{array}$} & \multicolumn{2}{|c|}{ Sesudah Reklamasi } \\
\hline & $\begin{array}{l}\text { Jumlah } \\
\text { responden }\end{array}$ & $\begin{array}{l}\text { Presentase } \\
\%\end{array}$ & Jumlah responden & $\begin{array}{l}\text { Presentase } \\
\%\end{array}$ \\
\hline$<$ Rp.1.000.000 & - & - & - & - \\
\hline $\begin{array}{l}\text { Rp.1.000.000- } \\
\text { Rp. 2.000.000 }\end{array}$ & 4 & $\begin{array}{l}18, \\
18\end{array}$ & 7 & $\begin{array}{l}31 \\
81\end{array}$ \\
\hline $\begin{array}{l}\text { RP. } 2.000 .000- \\
\text { Rp. } 3.000 .000\end{array}$ & 10 & 0,5 & 9 & $\begin{array}{l}36, \\
36\end{array}$ \\
\hline >Rp. 3.000 .000 & 7 & $\begin{array}{l}31, \\
81\end{array}$ & 7 & $\begin{array}{l}31, \\
81\end{array}$ \\
\hline Lainnya & - & - & - & - \\
\hline Jumlah & 22 & 100 & 22 & 100 \\
\hline
\end{tabular}

Sumber :data primer diolah 2017 
Berdasarkan pada table diatas dapat diketahui bahwa pendapatan masyarakat pesisir dengan tingkat pendapatan sebelum reklamasi tingkat pendapatannya di dominasi oleh masyarakat yang dengan tingkat pendapatan 2.000.000-3.000.000 dengan presentase $0,5 \%$, sementara sesudah reklamasi dengan presentasi $36,36 \%$. Selanjutya pendapatan 1.000.000-2.000.000 sebelum reklamasi dengan presentase $18,18 \%$ sementara sesudah dengan presentase 31,81 $\%$.pendapatan lebih kecil 1.000 .000 yaitu tidak ada yang memeliki pendapatan tersebut sebelum dan sesudah reklamasi.sedangkan pendapatan lebih besar dari 3.000.000 sebelum dan sesudah reklamasi dengan presentasi $31,81 \%$ dimana sama saja tidak ada perubahan.

Pada table responden menunjukan bahwa tingkat pendapatan sebelum dilakukan reklamasi pantai lebih tinggi dibandingkan sesudah reklamasi.hal ini disebabkan oleh pekerjaan pokok masyarakat yang mencari penghidupan dari laut.

Reklamasi pantai berdampak pada pendapatan masyarakat yang tinggal dan mencari nafkah diarea penimbunan laut dimana berdampak pula pada kesejahteraan masyarakat. Dampak tersebut merupakan dampak positif yang melibatkan masyarakat dengan jumlah yang banyak.Secara tidak langsung reklamasi berdampak pada pendapatan masyarakat peisisir laino yang mana setelah terjadinya reklamasi khususnya terhadap pendapatan nelayan tidak menentu .

Reklamasi pantai akan berdampak pada pendapatan masyarakat yang tinggal dan mencari nafkah diarea penimbunan laut dimana berdampak pula pada kesejahteraan masyarakat. Dampak tersebut merupakan dampak positif yang melibatkan masyarakat dengan jumlah yang banyak.Secara tidak langsung reklamasi berdampak pada pendapatan masyarakat peisisir laino yang maa setelah terjadinya reklamasi khususnya terhadap pendapatan nelayan tidak menentu sehingga dengan reklamasi masyarakat yang bekerja sebagai nelayan mencari pekerjaan tambahan mata pencaharian sebagian penduduk yang tinggal di area penimbunan.

\section{Faktor-faktor YangMenyebabkan DilakukanReklamasi.}

Reklamasi adalah suatu proses membuat daratan baru pada suatu daerah perairan/pesisir pantai atau daerah rawa. Hal ini umumya dilatarbelakangi oleh semakin tingginya tingkat populasi manusia, khususnya di kawasan pesisir, yang menyebabkan lahan untuk pembangunan semakin sempit. Pertumbuhan penduduk dengan segala aktivitasnya tidak bisa dilepaskan dengan masalah kebutuhan lahan. Pembangunan yang ditujukan untuk menyejahterakan rakyat yang lapar lahan telah mengantar pada perluasan wilayah yang tak terbantahkan.

Hal ini menyebabkan manusia memikirkan untuk mencari lahan baru, terutama daerah strategis dimana terjadi aktifitas perekonomian yang padat seperti pelabuhan, bandar udara atau kawasan komersial lainnya, dimana lahan yang terbatas luasan dan kondisinya harus dijadikan dan diubah 
menjadi lahan yang produktif untuk jasa dan kegiatan perkotaan.

Namun dalam hal ini bukan hanya masyarakat yang melakukan penimbunan akan tetepi reklamasi menjadi salah satu program pemerintah dalam membangun daerah terutama diarea pesisir.Sebelum dilakukan reklamasi pada pantai pesisir laino, pemerintah telah mensosialisasikan akan adanya peningkatan keamanan dan perbaikan di bidang pendidikan. Hal tersebut menjadi angin segar bagi masyarakat pesisir sekitar lokasi reklamasi pantai pesisir laino. Reaksi yang tergambar oleh masyarakat adalah terlihatnya kepedulian satu sama lain.pemerintah yang menjanjikan perbaikan pendidikan yang mengarah kearah perbaikan kualitas pendidikan bagi masyarakat pesisir laino. Akan tetapi janji pemerintah akan pendidikan bagi anak masyarakat pesisir tidak dirasakan oleh masyarakat pesisir

\section{PEMBAHASAN}

Penelitian ini membahas tentang
dampak reklamasi pantai terhadap
kondisi sosial ekonomi masyarakat
pesisir laino dikelurahan laiworu
kecamatan batalaiworu kabupaten muna
yang berkaitan dengan dampak
reklamasi terhadap dampak sosial
ekonomi.sesuai dengan penelitian yang
dilakukan oleh peneliti bahwa kondisi
sosial ekonomi masyarakat pesisir laino
termaksud dalam kategori yang cukup
baik dimana dengan adanya
penimbunan laut memberikan dampak
yang lebih baik dimana masyarakat
merasa terbantu dengan adanya
penimbunan laut karena mempermudah

akses tranportasi bagi masyarkat yang tinggal diarea penimbunan laut. Sementara itu dalam dalam kondisi sosial ekonomi masyarakat yang berpengaruh yaitu kondisi dibidang pendidikan,kesehatan, perumahan serta pendapatan masyarakat pesisir laino mengalami peningkatan sesudah reklamasi, pendapatan juga mengalami peningkatan.

Selain itu juga reklamasi lebih mengarah terhadap perubahan mata pencaharian yang beragam dimana masyarakat tidak hanya sebagian kecil yang menjadi nelayan dan sebagian juga bekerja sebagai pekerja bangunan dan pedagang serta PNS dengan itu dampak reklamasi terhadap ekonomi lebih banyak kearah positif .

Bidang kesehatan kemampuan membayar pengobatan menggunakan jamkesmas sebanyak 54,54\% sedangkan responden yang menggunkanan biaya sendiri dalam pengobatan ada sebanyak $45,45 \%$ dan kondisi kesehatan yang baik dimana sebanyak 22(86,36\%) responden mengaku bahwa keluarganya selalu dalam kondisi sehat sedangkan $3(13,63 \%)$ responden mengaku bahwa sebagian keluarganya dalam kondisi yang kurang sehat dalam 6 bulan terakhir .

Bidang perumahan .masyarakat pesisir laino kondisi perumhannya termaksud dalam kategori baik dimana perumahan respoden memeliki fasilitas yang bias diaktan baik dan kondisi perumahan mengalami peningkatan sesudah reklamasi

Dalam hal pendapatan masyarakat pesisir dengan tingkat pendapatan sebelum reklamasi tingkat pendapatannya di dominasi oleh 
masyarakat yang dengan tingkat pendapatan 2.000.000-3.000.000 dengan presentase $0,5 \%$, sementara sesudah reklamasi dengan presentasi $36,36 \%$. Selanjutya pendapatan 1.000.000-2.000.000 sebelum reklamasi dengan presentase $18,18 \%$ sementara sesudah dengan presentase 31,81 $\%$.pendapatan lebih kecil 1.000 .000 yaitu tidak ada yang memeliki pendapatan tersebut sebelum dan sesudah reklamasi.sedangkan pendapatan lebih besar dari 3.000.000 sebelum dan sesudah reklamasi dengan presentasi $31,81 \%$ dimana sama saja tidak ada perubahan.

$$
\text { Jadi dalam Penelitian ini }
$$

reklamasi memberikan dampak yang signifikan atau lebih menguntungkan bagi masyarakat yang tinggal diarea penimbunan laut dimana sebagian masyarakat tidak mempermasalahkan adanya penimbunan karena pada kenyataanya masyarakat yang tinggal di pesisir laino tidak semua menggantungkan hidup pada laut hanya sebagian kecil yang mencari penghidupan dilaut dan lebih banyak pekerjaan di darat dan tidak mempermasalahkan dengan adanya reklamasi jadi reklamasi pantai di pesisir laino lebih berdampak baik terhadap kehidupan sosial ekonomi masyarakat yang tinggal diarea pesisir laino.

\section{KESIMPULAN}

Berdasarkan rumusan masalah dan hasil penelitian ini dapat ditarik beberapa kesimpulan sebagai berikut:

1. Tingkat kesehatan masyarakat pesisir laino sebelum dan sesudah dilakukan reklamasi dalam kategori baik.
2. Tingkat kondisi perumahan masyarakat pesisir laino sesudah reklamasi mengalami peningkatan akan tetepi peningkatan yang terjadi bukan semata-mata akibat dari reklamasi akan tetapi seiring berjalannya waktu.

3. Tingkat pendapatan masyarakat pesisir laino sesudah reklamasi tidak jauh berbeda dengan sebelum akan tetapi setelah reklamasi banyak masyarakat pesisir laino mencari pekerjaan sampingan.

4. Reklamasi disetiap daerah memiliki alasan tersendiri dalam melakukan reklamasi seperti yang terjadi di pesisir pantai laino. Dimana penimbunan bukan hannya dilakukan pemerintah akan tetapi masyarakat sekitar yang membuka lahan untuk pemukiman.

\section{DAFTAR PUSTAKA}

Asballah dan Raja, 2003. Hubungan Reklamasi Pantai dengan Komponen Perkembangan Kawasan, Tesis, Program Studi MPKD, Program Pasca Sarjana UGM. Yogyakarta

Alibasyah R dan Nurul H, 2012. Dampak Ekologi, Sosial Dan Ekonomi Masyarakat Akibat Reklamasi Pantai Tapaktuan Aceh Selatan ProgramStudi Magister Konservasi Sumberdaya Lahan Unsyiah, Jurnal 
Manajemen Sumberdaya Lahan, Volume 1, Nomor 2, Desember 2012: hal. 171-178, (online)

Alifana, Laode .2011. Studi perbandingan kondisi sosial ekonomi masyarakatLocal dan masyarakat transmigrasi didesa lupia kecamatan kabangka Kabupaten muna. Skripsi : Fekon UHO. Kendari

Bintarto,1991.geografi manusia (Teori,Tema Dan Metodologi) Proc.Seminar Aplikasi Penelitian Geografi Untuk Perencanaan Pengembangan Wilayah,Fakultas Geografi Universitas Gajah Mada Yogyakarta.

Bintarto dan Surastopo.1982. Metode Analisis Geografi.LP3ES.Jakarta

Dicktus (2013) Defenisi Dampak Pengaendalian Hujan Asam Nikel .

Fauzi Wadi Afdal 2011. Alternatif Kebijakan Pengelolaan Pantai Kamali Hasil Reklamasi DiKota Bau-Bau Yang Memimumkan Dampak Lingkungan. Program studi pengelolaan sumber daya alam dan lingkungan Institut Pertanian Bogor.Bogor

Mustaqim Ibnu 2015. Dampak Reklamasi Pantai Utara Jakarta Terhadap Perubahan Sosial Ekonomi Masyarkat ( Tinjauaan Sosiologis Masyarakat Disekitaran Pelabuhan Muara
Angke,Kelurahan Pluit Jakarta Utara).skripsi Fakultas Ilmu Tarbiah dan Keguruan Universitas Islam Negeri Syarif Hidaytulah. Jakarta

Nurmandi,A, (1999), Manajemen Perkotaan :Aktor. Organisasi dan Pengelolan Perkotaan di Indonesia. Lingkaran Bangsa, Yogyakarta.

Soekanto,1990.Sosiologi Suatu Pengantar.Jakarta:PT Raja Grafindo Persada

Sugiyono,2012. Metode penelitian pendidikan,pendekatan kuantitatif, kualitatif dan $R \& D$.Bandung. Alfabeta

Sinaga Pariaman.2004. Pasar Modern VS Pasar Tradisional . Jakarta: Kementrian Koperasi dan UKM

Wagiu Max, 2011. Dampak Program Reklamasi Bagi Ekonomi Rumah Tangga Nelayan Di Kota Manado . Jurnal Perikanan dan Kelautan Tropis Vol. VII-1, April 2011 Fakultas Perikanan dan Ilmu Kelautan:UNSRAT. (online)

Wiryawan Budy 2012. Dampak Reklamasi Teluk Jakarta Terhadap Kegiatan Penangkapan Ikan Di Teluk Jakarta,fakultas bisnis dan ekonomi ITB universitas Jurnal Perikanan dan Kelautan Vol. II No. 2 :. Desember 2012 hal.105-112 (online) 